\title{
ALGORITHMIC POPULISM AND THE DATAFICATION AND GAMIFICATION OF THE PEOPLE BY FLEMISH INTEREST IN BELGIUM
}

\author{
POPULISMO ALGORÍTMICO E A DATIFICAÇÃO E \\ GAMIFICAÇÃO DO POVO PELO INTERESSE FLAMENGO \\ (VLAAMS BELANG) NA BÉLGICA
}

\section{Ico Maly}

\begin{abstract}
Populism studies tend to understand populism as a purely political phenomenon (MUDDE; KALTWASSER, 2017; MÜLLER, 2016). To categorize someone as a populist or not, is in many cases solely based on an evaluation of discourse, style or even ideology. It is much rarer to see approaches to populism that focus on the relation between politics and media and digital media in particular (welcome exceptions are CESARINO 2019 e SILVA, 2019). Throughout this contribution, I will argue that we cannot understand populism in full without focusing in detail on how populists and others actually construct the populist voice, how they communicate themselves on different platforms as the 'true representatives of the people'. This inevitably means taking the changing media landscape into account as a keycontext that shapes contemporary populism. The hybrid media system, its media logics, affordances and its culture of connectivity need to be considered when trying to make sense of populism and politics in general in the $21^{\text {st }}$ century.
\end{abstract}

Keywords: algorithmic populism; datafication; gamification; attention economy.

\section{RESUMO}

Os estudos sobre populismo tendem a entender o populismo como um fenômeno puramente político (MUDDE; KALTWASSER, 2017; MÜLLER, 2016). A categorização de alguém como populista ou não é em muitos casos apenas baseada numa avaliação do discurso, estilo ou mesmo ideologia. É muito mais raro encontrar abordagens do populismo centradas na relação entre política e mídia, em particular meios digitais (exceções bemvindas são CESARINO, 2019 e SILVA, 2019). Ao longo deste artigo, argumentarei que não podemos compreender plenamente o populismo sem nos concentrarmos em pormenor na forma como os populistas e outros constroem efetivamente a voz populista, como se comunicam em diferentes plataformas como os "verdadeiros representantes do povo". Isto significa, inevitavelmente, ter em conta a paisagem mediática em mutação como um contexto-chave que molda o populismo contemporâneo. $\mathrm{O}$ sistema híbrido das mídias, suas

\footnotetext{
* Tilburg School of Humanities and Digital Sciences, Department of Culture Studies, Tilburg, Netherlands. I.E.L.Maly@tilburguniversity.edu Orcid: https://orcid.org/0000-0001-7984-0974
} 
lógicas midiáticas, seus meios de comunicação e a sua cultura de conectividade têm de ser considerados quando se tenta dar sentido ao populismo e à política em geral no século XXI. Palavras-chave: populismo algorítimico; datificação; gamificação; economia de atenção.

Populism studies tend to understand populism as a purely political phenomenon (MUDDE; KALTWASSER, 2017; MÜLLER, 2016). To categorize someone as a populist or not, is in many cases solely based on an evaluation of discourse, style or even ideology. It is much rarer to see approaches to populism that focus on the relation between politics and media and digital media in particular (welcome exceptions are CESARINO 2019 and SILVA, 2019). Throughout this contribution, I will argue that we cannot understand populism in full without focusing in detail on how populists and others actually construct the populist voice, how they communicate themselves on different platforms as the 'true representatives of the people'. This inevitably means taking the changing media landscape into account as a key-context that shapes contemporary populism. The hybrid media system, its media logics, affordances and its culture of connectivity need to be considered when trying to make sense of populism and politics in general in the $21^{\text {st }}$ century.

Note, that I understand populism here in a very specific way, namely as a mediatized communicative relation and thus not as 'thin ideology'. Populism, I argue, is not only constructed in relation to journalists, politicians and academics, but also in relation with citizens, activists and computational agency. If we take media on board in our understanding of populism, then analyzing populism as a style or a discursive frame that politicians can use to appeal to the people and mobilize them is not enough. The affordances of digital media and Web 2.0 push us towards understanding populism as a digitally mediated communicative relation between different human and algorithmic actors, hence the notion of 'algorithmic populism'. Populism is not only about 'the input', the frame that actors prepare for uptake, it is about the uptake - the audience labour (FISHER, 2015) - as well. Populism, in this understanding, presupposes

1. A communicator that mobilizes an anti-elite discourse in the name of 'the people', that is somebody who can be labeled or labels him or herself as a populist or claims to speak in the name of the people.

2. A (claim to a) certain amount of knowledge of the demands and/or needs of (a part of) the people 'the populist' claims to represent (in many cases now acquired through datafication) 
3. Other actors like journalists, politicians and/or academics who label the communicator, party or movement as populist

4. A (digital) media infrastructure through which the message of 'the populist' is distributed and knowledge about the audience is gathered

5. And some kind of uptake, legitimation or recognition of (a part of) the people (in the form of likes, shares, followers, militants and voters)

Understanding populism as a communicative relation highlights that populism is the result of a complex interplay between all of these different elements. In the digital age, this interplay has resulted in a new type of populism, 'algorithmic populism' (MALY, 2018a, 2018b, 2018c), that is a populism that is at least partially reliant on applying algorithmic knowledge and activism in order to construct the populist voice and let it circulate throughout the hybrid media system.

Analyzing populism is thus analyzing this complex interplay. In this paper I will focus on the role of 'the people' in the construction of the populist voice in an attention-based hybrid media system (CHADWICK, 2017; VENTURINI, 2019). I will argue that the contemporary $21^{\text {st }}$ century populist uses the affordances of digital technology not only to attract the attention of common people and the legacy media, but to actually mobilize people to co-construct the idea that the party is truly representing 'the people'. More concretely, I will focus on how the Belgian extremeright party Flemish Interest (Vlaams Belang) uses digital technology (Facebook and the political engagement platform NationBuilder) to position themselves as the true representatives of the Flemish people against an elite that destroys its society, culture and identity. I will argue that the party not only datafies the people, but also uses the gamification options of those digital platforms to put themselves in the center of the political attention economy in Belgium and especially in the Flemish speaking part of the country: Flanders. While the datafication of the people refers to the collection of big data to target their audience, the gamification of the people refers to the application of game elements and principles to activate that audience in a techno-political context. The combination of datafication and gamification of the people, I have found, allows them to not only to steer information flows in the hybrid media system, but also to construct themselves as the 'voice of the people'.

\section{AUDIENCE LABOUR IN AN ATTENTION-BASED HYBRID MEDIA SYSTEM}

Digitalization has fundamentally reshaped and re-organized the fields of politics and media. In his seminal work, Chadwick (2017) argues that we now see a 
'chaotic transition period' in which 'old media' and 'newer media logics' interact with and are interdependent among each other. The result of the interaction and interdependence of those media logics in the reflexively connected social fields of media and politics is what he labels as the 'bybrid media system' (CHADWICK, 2017). Within that system different actors - be it politicians, influencers, journalists, activists or alternative media - try to 'create, tap, or steer information flows in ways that suit their goals and in ways that modify, enable, or disable the agency of others, across and between a range of older and newer media settings' (CHADWICK, 2017, p. XI).

In this highly competitive hybrid media system legacy media, social media and user generated content media just like politicians, activists and prosumers are trying to get attention for their message. The democratization of content production made attention a scarce good. Attention, and not information, is one of the main drivers of the hybrid media system and the digital economy (VENTURINI, 2019: 128; van DIJCK; POELL; De WAEL, 2018). In the commercialized attentionbased economy, web 2.0 and 'the prosumers' function as producers of raw data. The front office of the digital infrastructure is organized around keeping the users hooked (EYAL, 2016) and enabling them to become producers while the back office is set up to measure and quantify that activity. This infrastructure enables platforms to algorithmically rework user data to improve services for the user and to enable personalized communication strategies for those who are interested in the user's attention (ZUBOFF, 2019).

Audience labour (FISHER, 2015) is a crucial ingredient of the attentionbased economy. Clicks, shares, comments, views, posts, status-updates and reach are all data that are measured and organize visibility in the hybrid media system. It is audience labour that generates attention for one's message (see MALY, 2018b \& 2019) and helps steer the information flows. Only when people interact with the post of the politician will it become visible for others and thus potentially grab their attention and subsequently get the message out. It is not enough to produce 'content' to gain attention in a hybrid media system, politicians need to build a network that actively interacts with their message. This network is crucial to gain visibility and get people to pay attention and potentially influence people. Influence, as Gruzd \& Wellman (2014) argue, is now networked influence and this in two ways: "by occurring in social networks and by propagating through online communication networks."

Having 'influence' in the digital media landscapes starts with building an audience, a network that interacts with your message. Politicians, activists and influencers in general don't passively wait for uptake, but facilitate it, gamify it, pay for it, actively organize it or even make use of influencers, click farms and non-human 
activity like bots and bot-networks to trigger the algorithms (MALY, 2018a, 2018b; JACOBSON; GRUZD; KUMAR; MAI, 2019). This uptake is especially important for populists as reach, likes and followers are used in contemporary populist discourse to stress that they actually articulate the voice of the people (MALY, 2018a, 2018b, 2018c). Attention-based politics or populism thus means investing, not only in content, but also in building algorithmic knowledge (VARIS, HOU, 2019; MALY, 2018 \& in review), in developing an algorithmic imagination (BUCHER, 2017).

The changes in the media field have profound effects in the political field. Politicians do not just need to present themselves in the mainstream media, they (and their team) need to manage their visibility on a broad range of media to draw attention to their message (LEMPERT; SILVERSTEIN, 2012), gain electoral support and engage in a discursive battle to normalize their ideology (MALY, 2016). Especially for outsider parties, politicians and activists that are considered 'extreme' or 'populist' digital media bring new opportunities to have their voice circulating in the public sphere. Flemish Interest is one of these parties.

\section{FLEMISH INTEREST AND THE RECONFIGURATION OF FLEMISH BLOC POPULISM}

Flemish Interest is an extreme-right Flemish nationalist Belgian party that was established in 2004, after the party Flemish Bloc was convicted for propagating racism. The Flemish Bloc was established in 1978, as a regrouping of splinter parties of the more established Flemish nationalist party the Volksunie (The People's Union). Since the end of the eighties, and especially in the nineties of the $20^{\text {th }}$ century Flemish Bloc/Interest has had a huge impact on the political debate in Flanders and Belgium in general (BLOMMAERT, 2001 \& 2007; DE CLEEN, 2013). The party combined a very radical Flemish nationalist discourse with an even more radical anti-immigration rhetoric, efficient communication strategies and strong communicators like Filip Dewinter and Gerolf Annemans (BLOMMAERT, 2017). The leaders spoke with 'one voice' in name of the party and the Flemish people. Throughout the nineties and the first decade of the $20^{\text {th }}$ century the party was able to win election after election and make migration a key topic in the Flemish political landscape (DE CLEEN, 2013), influencing the mainstream parties and the legacy media (BLOMMAERT; VERSCHUEREN, 1998).

Flemish Bloc/Interest had developed a discourse that was made for uptake in the quickly changing media-landscape of the nineties in Flanders. Those were the years of the commercialization of the Belgian media landscape. Commercialization 
also came with new types of news: news for instance that focused on more controversial and sensationalist topics of which criminality-reporting took a large portion (MALY, $2007 \& 2009$ ). The controversy around the party and its radical discourse invoked massive attention and this attention not only made the party the agenda-setting party between 1991 and 2004, it also resulted in more than a decade of electoral victories. Dewinter used these electoral victories not only to claim that they were the largest party in Flanders, but also as part of his populist discourse (BLOMMAERT, 2001). When Flemish Bloc became the biggest party in 2004, they claimed that it was finally 'Time to listen to the voice of the voter' (ROOX, 2004). Not only the party itself presented itself as the voice of the people, this frame was also reproduced in the media by others. Each time the party managed to gain votes in an election, it was framed as 'a sign from the voters' (gr, 2004), from the people.

2004 was the last victory before the party started to lose votes to a new Flemish nationalist party, N-VA who also claimed to speak in name of the Flemings (MALY, 2012 \& 2016). In the national elections of 2007, Flemish Interest lost 220.000 voters compared to 2004. More and more analysts concluded that the party reached its highpoint. A period of electoral decline had begun: the party lost 8,86\% in the Flemish elections of 2009 and 7.7\% in the European elections. In 2014 the party suffered its heaviest loss in history. The party only had 3,67\% of the votes left for the Chamber and 5,92\% in the Flemish parliament. 2014 was the end of an era. Gerolf Annemans ended his presidency of the party. The old generation of Flemish Interest politicians were officially not leading anymore. In 2014, Tom Van Grieken became president of the party. That youngest party president in Belgian history had to start from scratch is still painfully visible, when one realizes that his victory tweet in 2014 only got 9 likes and 10 retweets.

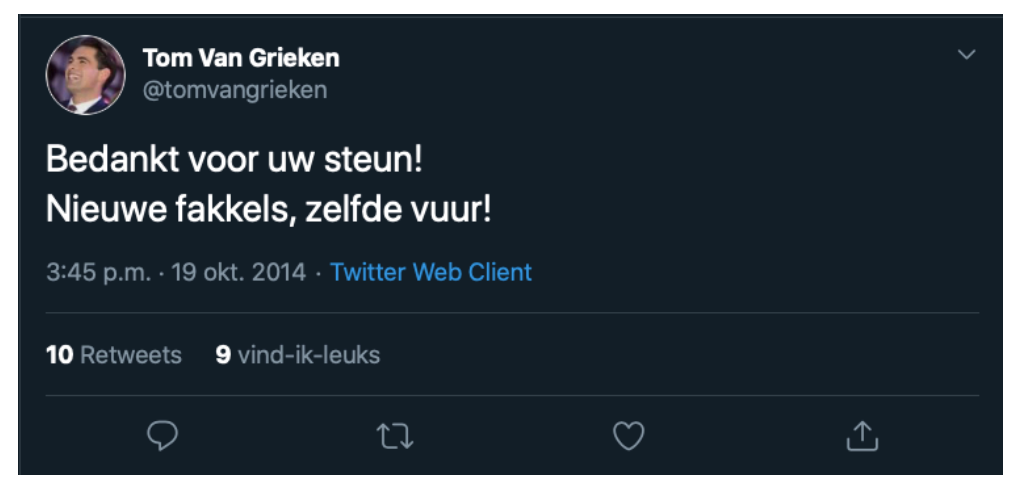

Image 1. Tweet from Tom Van Grieken, the newly elected president of Flemish Interest: Thank you for your support! New torches, same fire!" 
Van Grieken had four years to set himself and his party back on tracks. In his first years, backed by Annemans, he started to introduce new younger people in the party and started to create a digital strategy (see next section) and ideologically renewal of the party. This ideological renewal also came with the publication of a book: Toekomst in eigen band. Opstand tegen de elites (Future in our own bands. Revolt against the elites). Published in 2017, the book came just in time to relaunch the party with the elections of 2018 in sight. Even in the title, the populist frame is clearly visible: Van Grieken is portraying himself and his party as fighting 'the elites'. 'The people' writes Van Grieken 'want to be in power again (...) The elites, should again serve public interest instead of ignoring the will of the voters, making them look suspect or make fun of them.' (Van GRIEKEN, 2017a, p. 26). Not surprisingly, Van Grieken, claims to be fighting for the losers of globalism, the common man who is left behind (Van GRIEKEN, 2017b). It is also not a surprise that Van Grieken is happy to accept the label of 'populist as a badge of bonour' (Van GRIEKEN, 2017a: 25).

Even though the populist frame is quite similar as in the years of Dewinter and Annemans, the ideology and the general style have changed. Van Grieken clearly looks at the successes of the so-called 'populist revolt' since 2016 and adopts a similar combination of nationalist, anti-immigration and anti-globalism/ neoliberalism agenda with a strong focus on style and rhetoric. Nationalism is presented as an answer to globalism, delocalization, the decline of employment and the undermining of social security. Interestingly, a superficial look at Van Grieken's discourse showed not only a stress on more social issues, it also showed remarkable parallels with the discourse of Bart De Wever and the N-VA (MALY, 2012 \& 2016). Just like De Wever, our Flemish identity and our shared values got an enormous amount of attention in Van Grieken's book. This is the type of discourse that is hegemonic in Flanders and comes with a connotation of 'moderate right-wing'.

Van Grieken's book got an exceptionally favorable reception in the mainstream media. Especially his style was celebrated by the mainstream media who even labelled him 'the ideal son in law' (BRINCKMAN, 2017). The most popular newspaper of Flanders, Het Laatste Nieuws, claimed that his book was full of 'surprising ideas'. The renowned media-intellectual Jonathan Holslag not only wrote the preface but called Van Grieken 'a talented young force who commits to politics from an bonest concern about our society' (HOLSLAG, 2017). This framing of Holslag is remarkable, bound to generate attention and thus reproduced in mainstream media (De CEULAER, 2017). Not only Van Grieken as a person got favorable airtime in the legacy media, his book and its proposals were quite well received. In the preface and later interviews Holslag praised Van Grieken's stress on identity, national values 
and certain proposals. Brinckman, from the newspaper De Standaard, claimed that whereas the program is still radical, Van Grieken 'in bis language never takes things too far' (BRINCKMAN, 2017).

What most commentators missed was the re-alignment of the discourse of Flemish Interest with the Identarian tradition. The Identitarian tradition is inspired by new right authors like Guillaume Faye and Renaud Camus and became a visible activist force in the pan-European new right activist movement Generation Identity and Schild and Vriend in Flanders (MALY, 2019). The fact that this went unnoticed is remarkable, because in chapter 7 of his book, Van Grieken makes this affiliation very explicit. Defending the Flemish identity is at the heart of my party, Van Grieken writes (2017, p. 80): 'our singularity is pressurized by mass-immigration, islamization, political-correctness and the Belgian non-identity' (...) this phenomenon also occurs in other WesternEuropean countries. The French writer Renand Camus talks about 'Le grand replacement' or replacement immigration which replaces the native population and replaces it by allochthones.' (Van GRIEKEN, 2017, p. 80-81). Not only does Van Grieken here explicitly cite Renaud Camus, one of the key intellectuals of the Identitarian movement, he fully subscribes to the idea of 'replacement' and the Identitarian agenda and discourse. This Identitarianism also becomes visible in his plea for a new post-EU Europe as 'an association of free, independent and sovereign states that freely cooperate on some domains (...). He, again, wants a Europa were we all can be prond of, prond of our civilization and our patchwork of marvelous people and cultures" (Van GRIEKEN, 2017, p. 334).

The first major steps of Flemish Interest under the reign of Van Grieken used the media logic of the mass media. By publishing this book, with a preface of a renowned media intellectual, he not only got mainstream media airtime, he became known as 'different' from the old Flemish Bloc front men, using a different style and discourse. In 2018 Flemish Interest managed to grow a bit after a series of losing votes. Van Grieken's ideological, discursive and organizational renewal seemed to have paid off. What was less highlighted in mainstream media during 2018 and 2019 , was that he not only clearly invested in youth, or mass media communication, but also in social media communication.

\section{ORGANICALLY BUILDING AN ATTENTIVE FACEBOOK AUDIENCE}

Already in the first two pages of his book, Van Grieken pointed out that the Internet created an 'equal level playing' field that can enable the 'revolt of the people' (Van GRIEKEN, 2017, p. 22). Digital media were not only important as an argument in his populist discourse, they were also a key instrument to put the party back 
on the rails. One of the young people Van Grieken hired after his appointment was Bart Claes, future president of the youth division of Flemish Interest and a personal friend of Van Grieken (Van SCHEL, 2016). Claes became the social media manager of the party. When Claes started, Flemish Interest had around 20.000 likes on Facebook (SKEPTR, 2018). His self-declared goal was to build a digital community and to make sure that Flemish Interest was back on people's minds (KELEPOURIS, 2019).

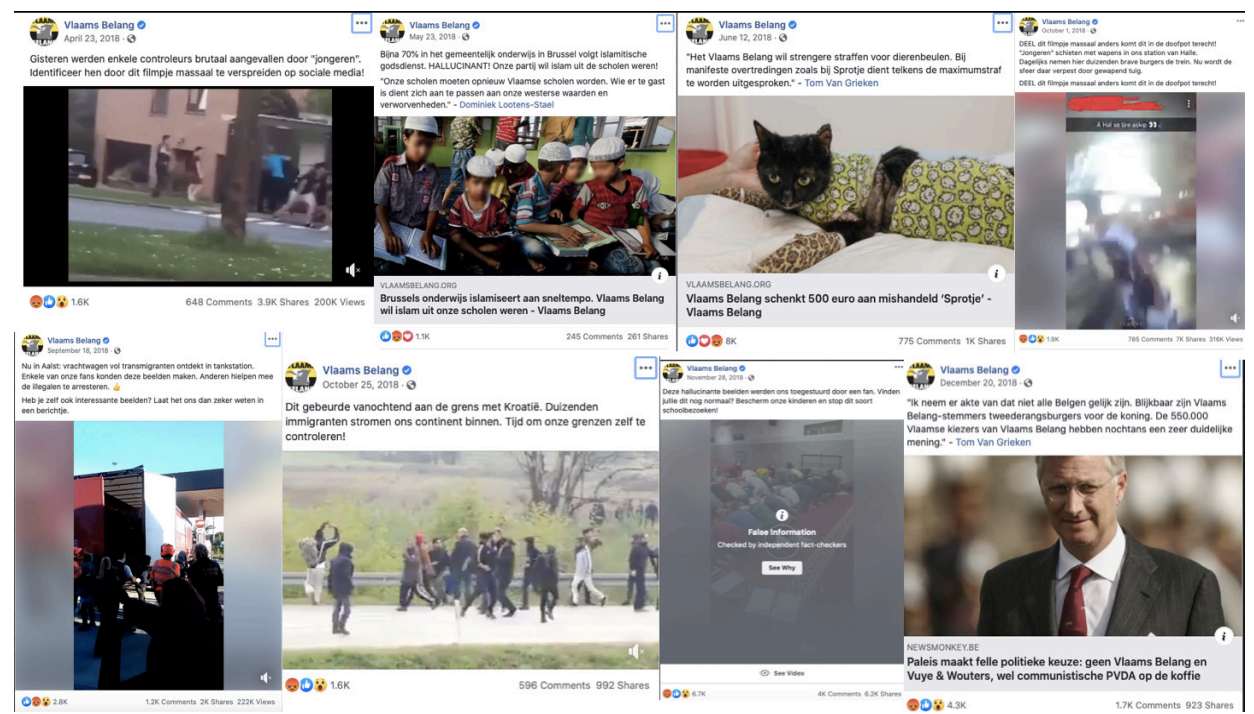

Image 2. Selection of viral posts of Vlaams Belang in 2018

Up until 2018, the party had only small budgets and limited staff of 2 people focusing on social media communication. Claes and his colleague therefore focused on 'engaging content' (SKEPTR, 2018). Image 2 shows a representative collection of the viral posts on the main Facebook page of the party in that year. Note that none of these posts has logos or slogans of the party on them. Several posts are uploads of vigilante cell phone videos, two of them link to a post on the official Flemish Interest website and one posts a link to the website of a Flemish news media. These posts don't have the looks of professional political communication, but come with a rawness and an air of 'authentic' 'parler vrai'. Topic-wise, these posts deal with 'massive immigration flows', 'islamization', 'escaped illegals', 'migrants rioting or figbting' and more surprisingly 'animal rights'. The different posts are all framed to spark outrage as visible in the use of keywords like 'ballucinatory', 'brutally', 'cover up' and in the focus on violence, danger, misbehavior and criminality. Many of these posts also come 
with calls towards their audience to share (to make sure that 'it could not be covered up' or to help 'identify the perpetrators'), to send in new vigilante videos or to comment.

Posting such alarming message to keep their followers mobilized is a classic ingredient of populism in the digital era (CESARINO, 2019). The focus is on affective posts, that spark outrage and generate direct reaction. These posts were not lucky shots, but explicit policy (SKEPTR, 2018) that helps generate organic uptake (MALY, BEEKMANS, 2018) and build an audience for the page. Claes himself stresses that 'A successful social media strategy combined with excellent knowledge of the Facebook Algorithm and creatively engaging with the news is of course of crucial importance'(NAEYAERT, 2018). Algorithmic knowledge was a crucial ingredient of the party's digital populism (CESARINO, 2019). Flemish Interest used the media logic of Facebook (and its stress on attention and engagement) and combined it with the older media logic of commercialized legacy media that focusses on controversy, sensation, danger and even Fake News to sell news (WU, 2016). In the process, the party has managed to build an active digital community or, in academic terms, a networked public that is connected and can be mobilized through expressions of sentiment. This 'affective public', as Papacharissi (2016) calls it, assembles around the Facebook page of Flemish Interest. This page allows the party to organize 'affective attunement' and 'propagate affectively charged expressions'.

The mobilization of this affective public can be illustrated by zooming in on a concrete post. A good example was their post from January 23, 2020 (see image 3). This post started its life with a retweet of a newspaper article from Het Belang van Limburg with the title 'Walker, age 73, has almost been beaten to death, a confused Afghan bas been arrested' (see image 3 ). 


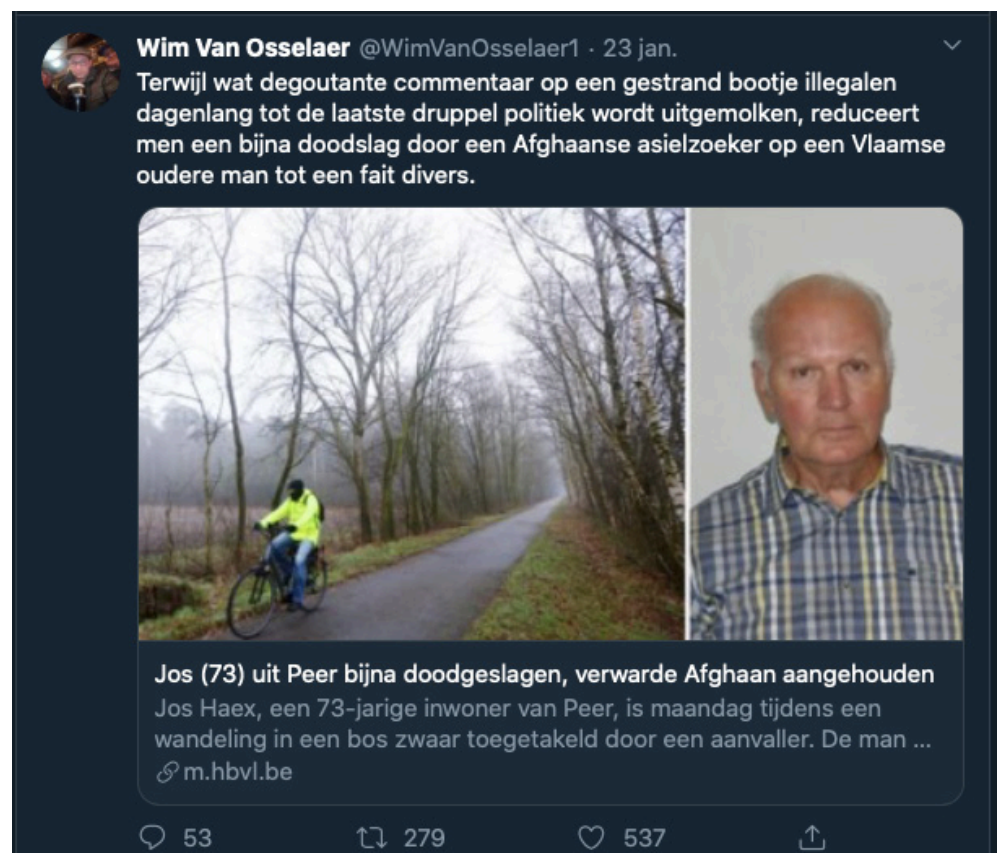

Image 3. Wim Van Osselaer (Flemish Interest) tweets newspaper article

Wim van Osselaer, Secretary of Flemish Interest in the Flemish Parliament was the first to tweet a link to this article at 8 o'clock in the morning together with a political message criticizing mainstream political parties in Flanders for their hypocrisy. He retweeted the article with the status: 'While some disgusting comments on a stranded little boat full of illegals is politically exploited for days in a row, one reduces the almost man slaughter by an Afghan asylum seeker on a Flemish older man to a fait divers'. It immediately generated substantial engagement. In total, 279 people retweeted it, and 535 liked the post. Among the retweeters were Tom Van Grieken, president of Flemish Interest, President of the Flemish Interest Fraction in the Flemish parliament Chris Janssens and Dries Van Langenhove, president of the Flemish Identitarian movement Schild \& Vrienden (MALY, 2019) and elected on the Flemish Interest list of Vlaams Brabant as an independent candidate. The post and the retweets did help to push Flemish Interests' main message, but drove traffic to the legacy media and didn't immediately generate political capital for Flemish Interest. Flemish Interest's social media quickly reproduced the news on their Facebook page in an image post published at 8:34h the same day (see image 4). 


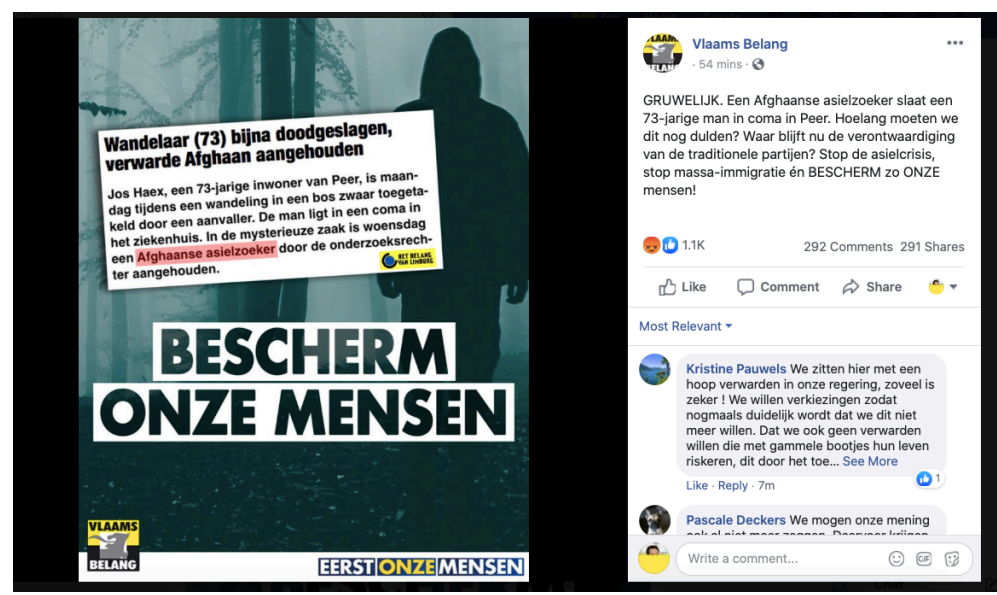

Image 4. Protect our people - First our people

The topic had already proven to be successful and useful, but the custom post would even enhance the viral characteristics of the orginal news article. The legacy media excerpt is pasted on top of a dark stock image showing a shadow of a person with a hoodie in foggy woods and accompanied with one of the known slogans of the party: 'protect our people' (Bescherm onze mensen). Below the image one sees the logo of the party and their key motto: 'First our people'. The sensationalist headline of the newspaper article is not only accompanied with the logo of the newspaper, it also comes with a summary in which 'Afghan asylum seeker' is highlighted with a pink marker. The status of the post reframes the news article in a political discourse: 'GRUESOME'. An Afghan asylum seeker beats a 73 year old man in a coma in Peer. How long should we take this. Where is the indignation now from the traditional parties? Stop the asylum crisis, stop mass immigration in order to PROTECT OUR people! The 'news' is presented as a direct consequence of the asylum policies of the mainstream parties, 'their open border policies' and their contribution to the Great Replacement. Note here, that the whole event is reframed in a populist discourse where only Flemish Interest fights to protect 'our people'. By reproducing the title, and intro of the newspaper article and the logo of the newspaper, it is not only re-using the newspapers quest for attention (and to sell newspapers) for its political goal, the recontextualization of the newspaper excerpt gives authority to its political message: immigrants threaten 'our' people and Flemish Interest is the only party that will protect them. Note also, that it is presented as a certainty that this asylum seeker has beaten the old man, whereas in the media article it is reported that the man sat next to the old man, and was so confused that he could not be interrogated. 
The assembled image amplifies the viral characteristics of the original article. Within the first 54 minutes the post generated $1.1 \mathrm{k}$ likes, 292 comments and 291 shares. The message is clearly constructed for online engagement and is readymade for uptake within the affective public hoovering around the Facebook page of the party. This uptake is not only produced by the post itself, it is at least as much the result the loyal affective networked audience that has been build up over the last years, the affordances of Facebook and the algorithmic knowledge and party discipline. Besides its national page, the party has many different local Flemish Interest chapters managing their own pages. Flemish Interest thus has a whole network of pages connecting different networked publics. Within a day, 14 local chapters of the party shared the post helping to boost it to their own local audiences.

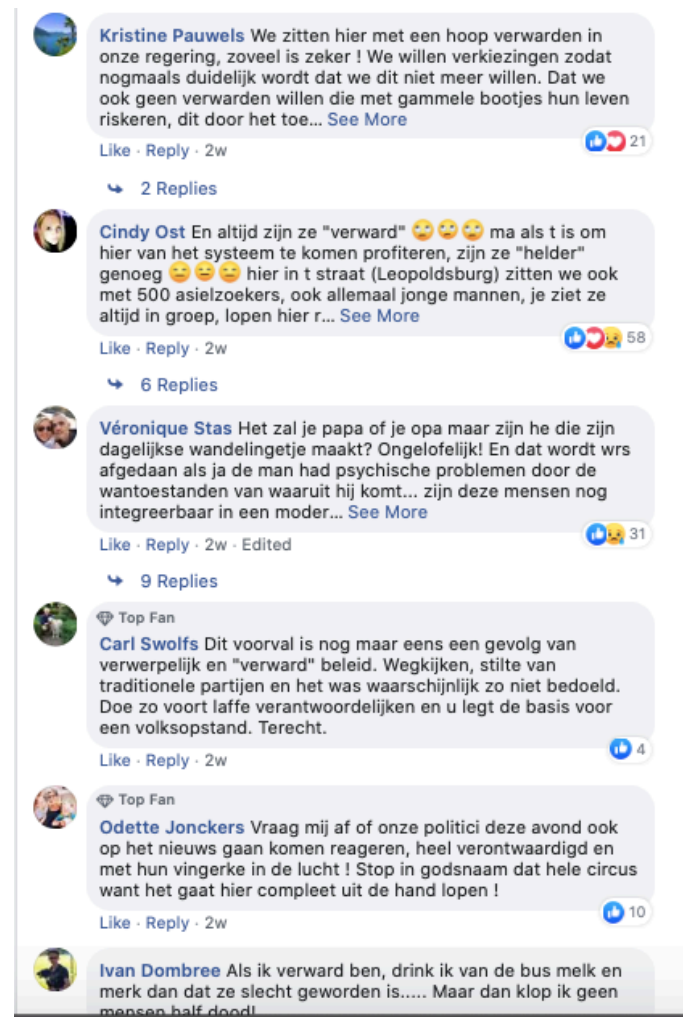

Image 5. consistent commenting

Most shares are done by militants and followers of the page and it is clear that the post immediately triggers outrage. $3.2 \mathrm{~K}$ of the $5.3 \mathrm{~K}$ interactions consists 
out of 'angry faces' and $1.7 \mathrm{k}$ support the message by using the thumbs up. The comments show enormous discursive consistency in reactions. Most comments focus on the use of the word 'verward' (confused) in the original newspaper article and read it as an indication that mainstream media are scared to tell the truth, a trope that was also used regularly in the 2018-posts when the party was building its audience. Another consistent theme is the fact that in Belgium one cannot speak up about migrants and criminality. What is very noticeable is the large amount of profiles with a 'top fan' badge that comment the post (see image 5).

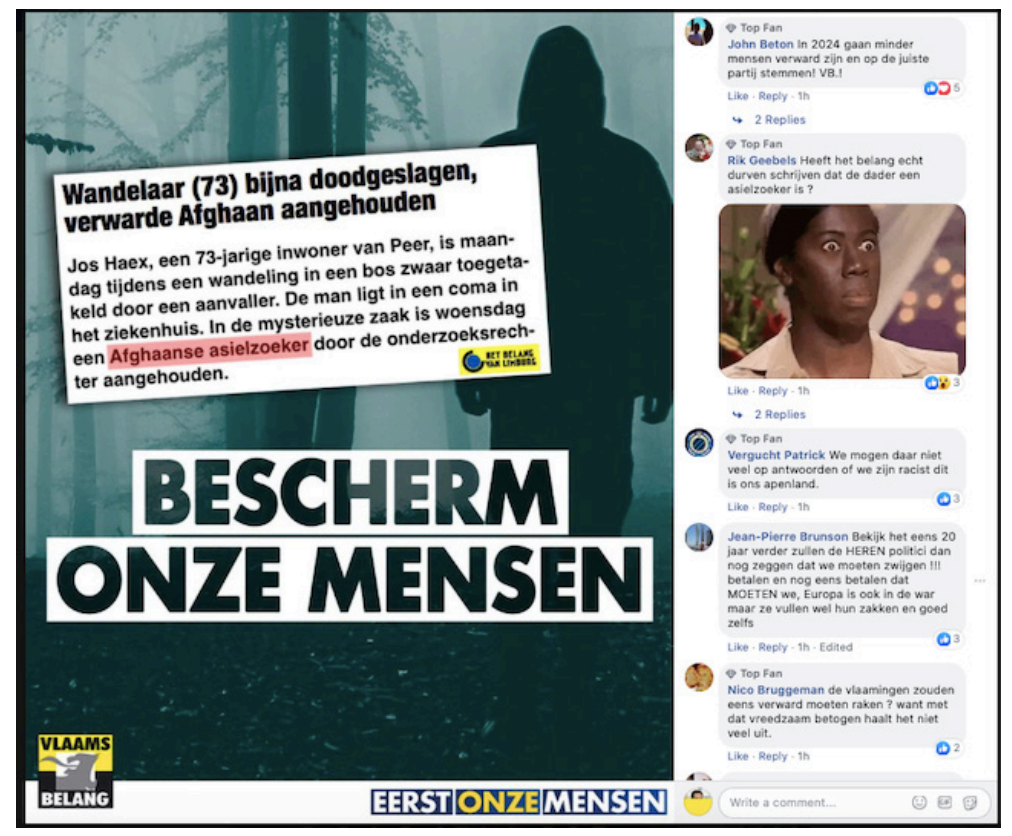

Image 6. Top Fans commenting on the Facebook Post

Flemish Interest has over the last few years been able to use the new affordance of Facebook to build a digital community. Since 2018, Facebook has been reorganizing its platform around communities and events, the feature of Top Fans on Facebook was part of that reorganization. The Top Fan label is algorithmically awarded on a weekly basis to the fans who are most active on the page. Active 'can include watching the Page's videos, liking or reacting to its content, and commenting on or sharing its posts' (FACEBOOK, 2020). With the Top Fans label, Facebook introduced gamification to make 'fans' more active and thus helps in producing 'organic' viral content. At the same time, this gamification gives admins more data and thus more 
explicit insight into what drives engagement among their audience, knowledge that will prove very useful, not only for organic but also for paid posts.

\section{FACEBOOK ADS TO UPSCALE AND THE 'DATAFICATION THE PEOPLE'}

Flemish Interest spend more than one million euro on Facebook ads in their 2019 campaign and are still using the ad-system of Facebook after their successful election result in 2019. Since March 2018, the main Facebook page of the party has spent 804.000 euro (of which 600.000 was spend before the elections of 2019) and the page of president Tom Van Grieken spent 376.352 euro on Facebook advertisements (30 January 2019). If we analyze the Facebook Ads that ran between March 2018 and 26 May 2019, the election day, we see the following topics in order of importance: Migration/Islam (38\% of the ads), Social issues (pensions, lower taxes on electricity) (12\%), Police and Justice (9\%) and Animal rights (4\%). 14\% of the messages were self-promotional and $17 \%$ were about purely political topics like the Cordon Sanitaire or framing other parties and party (leaders) as bad. The topics clearly show that the classic tropes of the Flemish Bloc era are still central in the 2019 campaign, but that a social dimension and animal rights perspective was added. Not surprisingly, the topics of the paid ads show great consistency with their viral organic posts. The set-up of all the ads was similar in the sense that they combine text, a telling image and the like button of their Facebook page. Most of the ads came with the same call to action: 'like if you agree'. Next to message politics, the ads were clearly set up to further build the audience of the page.

The dual strategy of engaging organic and paid posts to build a digital community worked. Already by 2016, Van Grieken could point out that his party, even though the polls showed a status quo, was doing very well as it had become 'the second largest party on social media' (SN, 2016). In August 2018, with 143.000 likes on Facebook the party became the Flemish political party with the most likes on Facebook. By the end of the year 2018, the party already had more 300.000 likes and in May 2019 it reached 395.000 likes. Becoming the biggest party on Facebook is immediately 'news' in the legacy media (Van der AUWERA; ARTOIS, 2018) which generates even more positive attention for the party. Van Grieken didn't let the opportunity pass to stress their broad popular base: 'We bave noticed a rise in our likes for some time now. Not only that, we have also seen a boost in membership of the party: that means that our message resonates, now more than ever' (Van DER AUWERA; ARTOIS, 2018). The likes help frame the party as not only as winners or popular, but as the party that is 'truly' articulating the voice of the people. Each time legacy media report on that 
social media success is a discursive opportunity to show the party as popular and to use these likes within a populist frame.

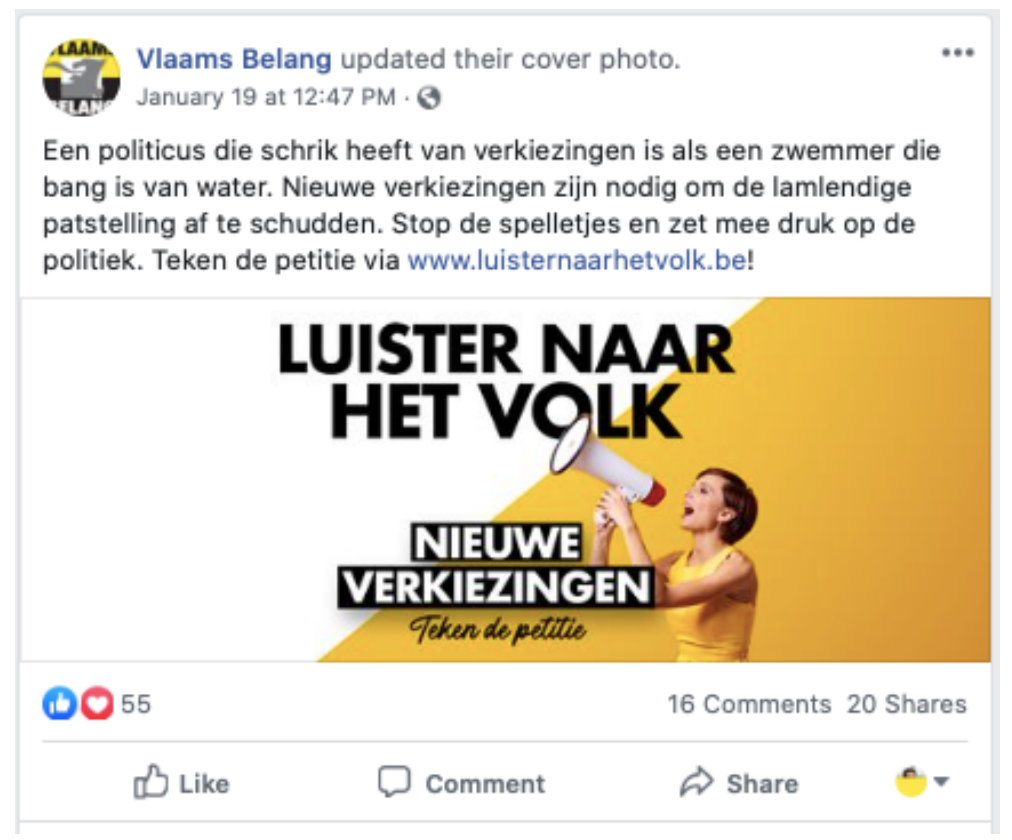

Image 7. new cover picture on Facebook page Flemish Interest

An interesting case to illustrate this dynamic between audience growth, engagement and the populist voice is the campaign that the party started on 19 January 2020. The start of this hybrid mobilization campaign (CHADWICK, 2017 was the launch of an online petition to organize new elections. The audience of the page was asked to help 'create pressure on politics' by signing the petition and 'the politicians' (read the elite, the mainstream) was asked 'to listen to the people' (Luister naar het volk). The whole campaign is soaked in a populist frame; the petition not only went under the name 'listen to the people', the URL of the petition was www. luisternaarhetvolk.be (which would translate to www.listentothepeople.be). After a new campaign banner for the page was uploaded, a post appeared on the timeline with the same message and image. The post was sponsored two times for around 300 euros each and managed a reach well over $100 \mathrm{~K}$, and get $6.9 \mathrm{~K}$ of interactions, 576 comments and $1.5 \mathrm{~K}$ shares (30 January 2020). The campaign was immediately distributed by press agency Belga as news. The campaign made it onto the websites of Het Nieuwsblad (SN, 2020) and Het Laatste Nieuws the most popular and bestread newspaper in Flanders (TT, 2020). 


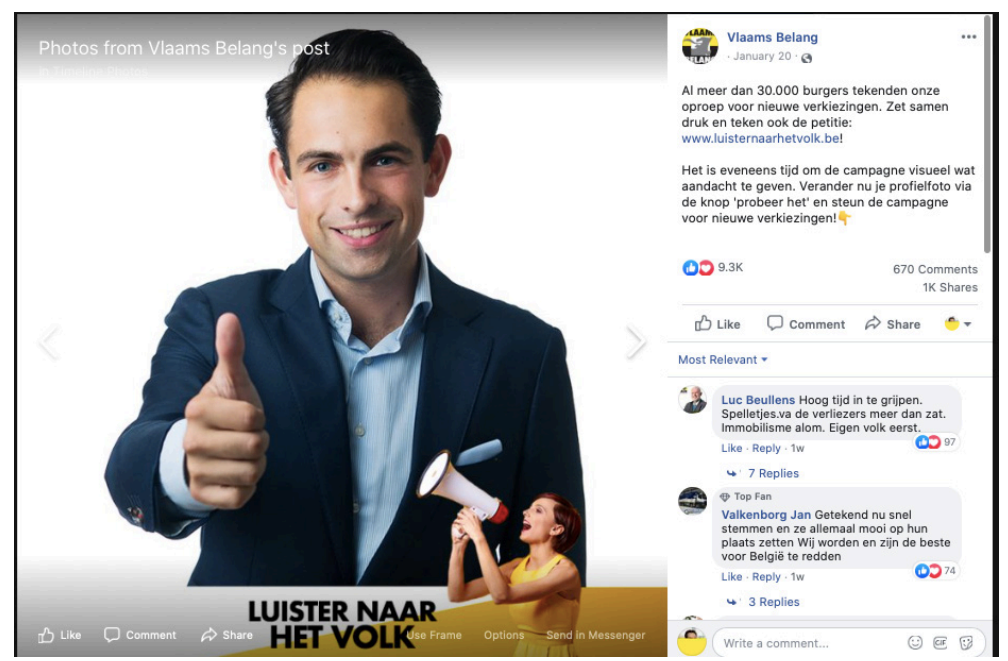

Image 8. Mobilizing the audience

The next day, on 20 January over 30.000 people had surfed to the website and signed the petition. In the next weeks, several new ads were launched to further promote the campaign. First in the row, was a post showing Tom Van Grieken with a profile pic banner of the campaign asking the followers to change their profile pic in order to give the campaign more airtime (see image 8). Such collective changes of one's profile pics function as memetic signifiers helping to construct a collective identity (GERBAUDO, 2015), to shape that digital affective public into community. In the next days and weeks, the campaign was further flagged in a series of organic posts and in several promoted campaign videos of 'common people' reproducing the message of the campaign and co-constructing the populist claim. In total a minimum of 9.000 euro and a maximum of 11.094 euro was spent on the campaign (3 February 2020). On January 24 already 50.000 people signed the petition and 3 days later another 10.000 signed. By the end of the month, the party started to publish a series of posts with quotes from famous politicians, journalists and academics (see image 9) seemingly supporting their call for new elections. 
Ook professor Carl Devos (UGent) ziet als politicoloog de situatie steeds meer afstevenen op een totale patstelling. Wanneer de politiek blokkeert, moet de bal in het kamp van de kiezer komen te liggen. Tijd voor nieuwe verkiezingen! Onderteken hier onze petitie:

www.luisternaarhetvolk.be.

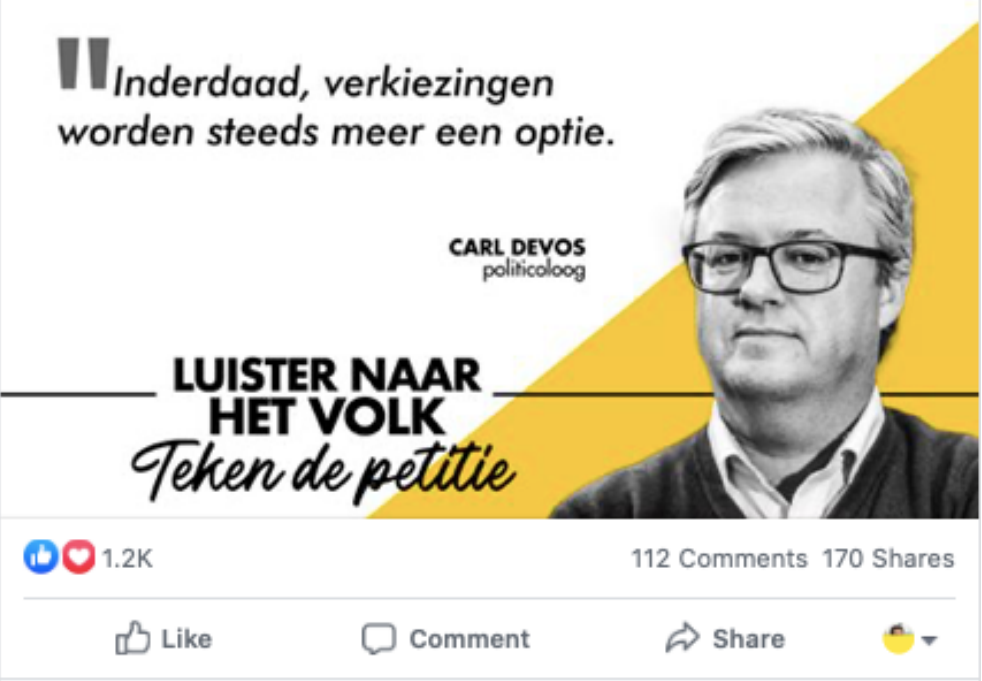

Image 9. one post from a series of famous Flemings seemingly supporting the campaign

By January 29, the legacy media picked up the message and the public broadcasting company VRT invited Tom van Grieken in their news talk show TerZake to reflect on the formation talks and potential new elections (TERZAKE, 2020). Van Grieken of course didn't only reflect on the question posed by the interviewer, he also used the opportunity talk about their campaign and the fact that now already 70.000 people signed their petition. Ergo, that 'the people' are fed up with the endless formation talks. The campaign illustrates not only how Flemish Interest successfully uses the populist frame and the affordances of Facebook to articulate its political position and steer the information flow in the hybrid media system (CHADWICK, 2013), it also illustrates how they use this populist frame and the affordances of Facebook to dataficate 'the people'. What most commentators missed is that the petition is made in NationBuilder and should thus be understood, not only as a means to put pressure on the other political parties or to steer the 
information flow and gain airtime in the legacy media, but as a way of organizing its personalized communication relation with potential future voters.

NationBuilder is a non-partisan, global commercial player in the world of politics, a so-called 'political engagement platform'. In essence, it allows parties to build a database of supporters ànd to track 'this nation' of potential voters, volunteers, staffers and party elites. This datamining does not only happen on their own platforms, NationBuilder mines all public social media activity. From a tweet posted or a Facebook like, to donating to the party (or canceling a donations) (O'CONNER, 2020), NationBuilder allows parties to capture that data and use it to build a profile of each member of their nation. All online behavior that is mined, is used to allocate a certain political capital of each individual member of the party's 'nation'.

\begin{tabular}{l|l|}
\hline STANDARD \\
PETITION
\end{tabular}

Image 10. NationBuilder- E-book on Petition Campaigns

This tracking of individuals is used in a system that 'allows for the gamification of politics' by creating a 'system of rewards designed to elicit optimal user behavior' (MCKELVEY; PIEBIAK, 2016, p. 910). The data can be used 'to pull supporters up the ladder of engagement - from petition signers to bigher value supporters like donors and volunteers' (BARLOW, 2012 ).The underlying goal of the campaign is thus found in datafiying the people and activating, mobilizing those people not only to sign this particular petition or to share it on social media and use mail to invite friends and family to sign it, most importantly it used to identify successful leaders and their networks and seduce them into taking action in the future. The incentive mail to share is thus not the last step. NationBuilder gives the example of a third step after that a user has actually signed and shared the petition, they can get contacted to do more for the party and for instance get rewarded with free tickets to a meeting or a get together. 


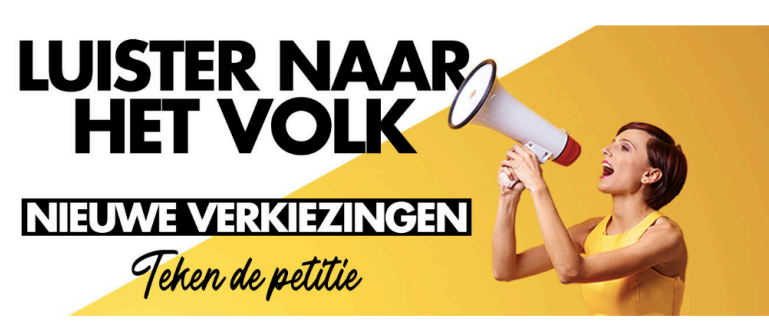

\section{BEDANKT!
HELP JE ONS MET DELEN?}

Luister naar het volk en organiseer nieuwe verkiezingen! Kopieer de link of deel via onderstaande knoppen.

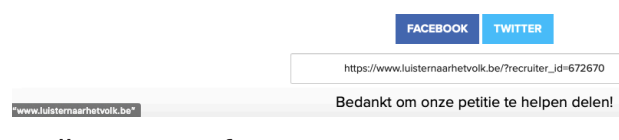

Image 11. call to action after signing

The petition itself is thus only a small part of a larger campaign. According to NationBuilder petitions are only successful if it "harnesses rich engagement data about your leaders (who's sharing the petition, who's recruiting peers to sign it) to drive more action from more people' (NATIONBUILDER, s. d.). NationBuilder allows Vlaams Belang to mine all that data and the system algorithmically translates this is in 'Political Capital' of the users, allowing the party to identify the true fans and give them more incentives to be active for the party. It is this surveillance and activation through datafication and gamification that allows the party to get noticed in the long term. In an attentionbased hybrid media system, spotting influence and influential people is important to politicians (GRUZD; WELLMAN, 2014, p. 4), as these influential people will potentially reproduce your message, recruit new people and help you build a movement.

\section{ALGORITHMIC POPULISM IN AN ATTENTION-BASED HYBRID MEDIA SYSTEM}

This paper illustrates that populism is not only constructed in a (mediatized) communicative relation between journalists and politicians, but also in the relation to citizens, activists and computational agency (MALY, 2018, p. 1). Contemporary populism is not just a frame, or a style that is used to normalize an ideology, it is also a sociotechnical assemblage. Datamining and gamification through hightechnological engagement platforms are key-ingredients of contemporary populism. Populism is a communicative relation in which mediatized uptake is as important as the supply side. A focus on the algorithmically organized uptake of messages and 
spread of message is crucial in any contemporary understanding of populism. They are politically facts.

Populism scholars have to take the algorithmic nature of the different social media platforms into account. The algorithmic nature of digital media contributes to the construction of a new type of populism, adapted to this new digital ecology. Digital media are not only used to let the 'populist' articulate and claim 'the voice of the people', it also formats that voice and makes sure that it circulates through many platforms and eventually when successful, is also picked up and reproduced as the voice of the people in legacy media. Populism is the normalizing vehicle of a political discourse and ideology. Even more, reach, followers, likes and attention are now not only crucial ingredients of the populist discourse, the populist discourse is also used to get more data which helps the party to build and activate its network and expand its networked influence in the attention-based hybrid media system.

\section{REFERENCES}

Van der AUWERA, J.; ARTOIS, J. (2018). Niet N-VA, maar wel Vlaams Belang is de grootste partij op Facebook. Het Laatste Nieuws. Available at: https://www.hln.be/ nieuws/binnenland/niet-n-va-maar-wel-vlaams-belang-is-de-grootste-partij-opfacebook abf60006/

BARLOW, K. (2012). Turning petitions into action for labor, environment. NationBuilder. Available at: https://nationbuilder.com/turning_petitions_into_action_for_labor_ Environment

BLOMMAERT, J. (2001). I stel vast. Politiek taalgebruik, politieke vernienwing en verrechtsing. Berchem: Epo.

BLOMMAERT, J. (2007). De crisis van de democratie. Berchem: Epo.

BLOMMAERT, J. (2017). 25 years of right wing extremism in Flanders. Diggit Magazine. Available at: https://www.diggitmagazine.com/articles/25-years-right-wing-extremism-belgium

BLOMMAERT, J.; VERSCHUEREN, J. (1998). Debating diversity. Analysing the discourse of tolerance. London \& New York: Routledge.

BRINKMAN, B. (2017). Ideale schoonzoon vrgt. eerlijke kans. Vlaams Belang-Voorzitter Tom Van Grieken Schrijft Een Boek. De Standaard. Available at: https://www. standaard.be/cnt/dmf20170503_02865028 
CHADWICK, A. (2017). The bybrid media system. Politics and power. New York: Oxford University Press.

CESARINO, L (2019). On digital populism in Brazil. PoLAR: Political and Legal Antbropology Review. Available at: https://polarjournal.org/2019/04/15/on-jair-bolsonaros-digitalpopulism/

De CEULAER, J. (2017). "Ik voel sympathie voor zijn strijdlust". De Morgen. Available at: https://www.demorgen.be/nieuws/ik-voel-sympathie-voor-zijn-strijdlust〜be5fadc3/

De CLEEN, B. (2013). The stage as an arena of Political Struggle: The Struggle between Vlaams Blok/Belang and the Flemish City Theatres. In: Wodak, R., KhosraviNik, M. \& Mral, B. (Eds.). Right-Wing populism in Europe. Politics and Discourse. London \& New Delhi: Bloomsburry.

EYAL, N. (2014). Hooked. How to build babit-forming products. London: Penguin.

FACEBOOK. (2020). What is a top fan badge on Facebook? Available at: https://www. facebook.com/help/215734232362020

FISHER, E. (2015). CLASS STRUGGLES IN THE DIGITAL FRONTIER: AUDIENCE LABOURTHEORY AND SOCIALMEDIAUSERS.INFORMATION, Communication \& Society. v. 18, n. 9, pp. 1108-1122. DOI: 10.1080/1369118X.2015.1018300

GERBAUDO, P. (2015) Protest avatars as memetic signifiers: political profile pictures and the construction of collective identity on social media in the 2011 protest wave. Information, Communication \& Society. v. 18, n. 8, pp. 916-929. DOI: 10.1080/1369118X.2015.1043316

GR. (2004). (gr) Zure Zondag geeft sterk déja vu-gevoel. De Standaard. Available at: https://www.standaard.be/cnt/gsk6m794

GRUZD, A., \& WELLMAN, B. (2014). Networked Influence in Social Media: Introduction to the Special Issue. American Behavioral Scientist, 58(10), 1251-1259. https:// doi.org/10.1177/0002764214527087

HOLSLAG, J. (2017). Voorwoord. In: Van Grieken, T. (Ed.). Toekomst in eigen handen. Opstand tegen de elites. Uitgeverij van Praag.

JACOBSON, J., GRUZD, A., KUMAR, P., \& MAI, P. (2019). Networked Influence: An Introduction. Social Media + Society. v. 5, n. 3, pp. 1-5. https://doi. org/10.1177/2056305119865473 
KELEPOURIS, S. (2019). Hoe Vlaams Belang via Facebook de verkiezingen won. De Morgen. Available at: https://www.demorgen.be/politiek/hoe-vlaams-belang-viafacebook-de-verkiezingen-won b2958a3f/

LEMPERT, M. \& SILVERSTEIN, M. (2012). Creatures of politics. Media, message and the American Presidency. Bloomington \& Indianapolis: Indiana University Press.

MALY, I. (ed.) (2007). Cultu(u)rENpolitiek. Over media, globalisering en culturele identiteiten. Antwerpen: Garant.

MALY, I. (2009). De Beschavingsmachine. Wij en de Islam. Berchem: Epo.

MALY, I. (2012). N-VA, Analyse van een politieke ideologie. Berchem: Epo.

Maly, I. (2016). 'Scientific' nationalism: N-VA and the discursive battle for the Flemish nation. Nations and nationalism. v. 22, n. 2, pp. 266-286. https://doi.org/10.1111/nana.12144

MALY, I. (2018a). Nieuw Rechts. Berchem: Epo.

MALY, I. (2018b). Algorithmic populism and algorithmic activism. Diggit Magazine. https:// www.diggitmagazine.com/articles/algorithmic-populism-activism

MALY, I. (2018c). Populism as a mediatized communicative relation: the birth of algorithmic populism. Tilburg Papers in Culture Studies. v. 213. https://www.tilburguniversity.edu/ sites/tiu/files/download/TPCS_213_Maly_2.pdf

MALY, I. (2019). New Right Metapolitics and the Algorithmic Activism of Schild \& Vrienden. Social Media + Society. v. 5, n. 2, pp. 1-15. https://doi.org/10.1177/2056305119856700

MALY, I., \& BEEKMANS, I. (2018). Research report: Analyzing Facebook's guidelines for publishers. Diggit Magazine. Available at: https://www.diggitmagazine.com/workingpapers/research-report-diggitday-facebook-experiment

MCKELVEY, F. \& PIEBIAK, J. (2018). Porting the political campaign: the NationBuilder platform and the global flows of political technology. New Media \& Society. v. 20, n. 3, pp. 901-918. DOI: 10.177/1461444816675439

MUDDE C. \& KALTWASSER, C.R. (2017). Populism. A very short introduction. Oxford: Oxford University Press.

MÜLLER, J.W. (2016). What is populism. Philadelphia: Pennsylvania Press. 
NATIONBUILDER. (s.d.). GUIDE. Organizing a successful petition campaign. Nationbuilder. Available at: https://d3n8a8pro7vhmx.cloudfront.net/3dna/pages/23862/attachments/ original/1438640947/nationbuilder-petition-guide.pdf? 1438640947

O'CONNER, (2020). Understanding virtual currency. NationBuilder. Available at: https:// support.nationbuilder.com/en/articles/2362765-understanding-virtual-currency

PAPACHARISSI, Z. (2016) Affective publics and structures of storytelling: sentiment, events and mediality. Information, Communication \& Society. v. 19, n. 3, pp. 307-324. DOI: 10.1080/1369118X.2015.1109697

ROOX, G. (2004). WINNAAR. Filip Dewinter. De schutskring staat op springen. De Standaard. Available at: https://www.standaard.be/cnt/gka6ldmi

SKEPTR, (2018). 'Bart Claes: "Grappig hoe partijen met marketingbureaus amper resultaten boeken"'. YouTube. Available at: https://www.youtube.com/watch?v=H8mI96wInDY

SN, (2016). Van Grieken over Vlaams Belang: "Ik denk dat de toekomst ons toelacht". De Morgen. Available at: https://www.demorgen.be/nieuws/van-grieken-over-vlaamsbelang-ik-denk-dat-de-toekomst-ons-toelacht bfd12c24/

SN, (2020). Vlaams Belang lanceert petitie voor nieuwe verkiezingen: "Luister naar het volk". Het Nieuwsblad. Available at: https://www.nieuwsblad.be/cnt/dmf20200119_04811640

TERZAKE, (2020). Federale formatie. Canvas. Available at: https://www.vrt.be/vrtnu/ a-z/terzake/2020/terzake-d20200129/\#autoplay $=62 \&$ asset $=/$ content $/$ dam/ vrt/2020/01/29/terzake-r2020-a0017-depot_WP00167375

TT, (2020). Vlaams Belang lanceert petitie voor nieuwe verkiezingen: "Luister naar het volk". Het Laatste Nieuws.

Van GRIEKEN, T. (2017a). Toekomst in eigen banden. Opstand tegen de elites. Uitgeverij van Praag.

Van GRIEKEN, T. (2017b). Wel, de toekomst, die behoort ons toe, en daarmee bedoel ik de terecht boze burgers. De Morgen. Available at: https://www.demorgen.be/meningen/ wel-de-toekomst-die-behoort-ons-toe-en-daarmee-bedoel-ik-de-terecht-bozeburgers ba094f49/

VARIS, P., \& HOU, M. (in press). Digital approaches in linguistic ethnography. In: Tusting, K. (Ed.). The Routledge handbook of linguistic etbnograpby. Abingdon, UK: Routledge. 
WU, T. (2016). The attention merchants. The epic struggle to bet inside our beads. London: Atlantic Books.

VENTURINI, T. (2019). From fake to junk news. The data politics of online virality. In: Bigo, D., Engin, I. and Ruppert, E. (Eds.) Data Politics. Worlds, subjects, rigbts. London \& New York: Routledge.

van DIJCK, J., POELL, T. \& De WAAL, M. (2018). The platform Society. Public values in a connective world. Oxford: Oxford University press.

Van SCHEL, W. (2016). Praten met Bart Claes. Pallieterke. Available at: https://pallieterke. net/2016/02/praten-met-bart-claes/

ZUBOFF, S. (2019). The age of surveillance capitalism. London: Profile Books.

Recebido: 11/02/2020

Aceito: 23/03/2020

Publicado: 13/04/2020 